\title{
The Challenges of Islamic Organisations in Promoting Moderation in Indonesia
}

\author{
Hasse Jubba $^{1 *}$, Jaffary Awang'2, Siti Aisyah Sungkilang ${ }^{3}$ \\ 1 Islamic Politics, Universitas Muhammadiyah Yogyakarta, Indonesia; e-mail: hasse@umy.ac.id \\ 2 Faculty of Islamic Studies, National University of Malaysia; e-mail: jaffary@ukm.edu.my \\ 3 Ankara University, Turkey; e-mail: sungkilang@ankara.edu.tr \\ * Correspondence
}

Received: 2021-06-16; Accepted: 2021-07-01; Published: 2021-08-10

\begin{abstract}
Two leading Islamic organisations in Indonesia, Muhammadiyah and Nahdlatul Ulama (NU) have moderation in their missionary vision to create a tolerant, open, and civilised society. This paper explores the challenges of realising Islamic moderation in Indonesia, especially those driven by Muhammadiyah and NU. The data used as the basis for the analysis were obtained from interviews and document studies. The challenge of Islamic moderation initiated by these two organisations is the rise of conservative groups, which have received vast space from the data obtained. This paper emphasised that the rise of conservative groups has resulted in weak respect for other groups. There is even a tendency to resist Islamic groups outside their group. This paper is limited to the internal challenges to Islamic moderation in Indonesia carried out by Muhammadiyah and NU, particularly related to the rise of conservative Islamic groups. Therefore, this paper suggests conducting various studies to provide a basic framework for jointly building a commitment to implement Islamic moderation in Indonesia by looking at other civil society organisations.
\end{abstract}

Keywords: Challenges; conservatism; Islamic moderation; Islamic organisation; social recognition.

Abstrak: Dua ormas Islam terkemuka di Indonesia, Muhammadiyah dan Nahdlatul Ulama (NU), memiliki visi misi yang moderat untuk mewujudkan masyarakat yang toleran, terbuka, dan beradab. Tulisan ini mengupas tentang tantangan mewujudkan moderasi Islam di Indonesia, khususnya yang dimotori oleh Muhammadiyah dan NU. Data yang digunakan sebagai dasar analisis diperoleh dari wawancara dan studi dokumen. Data penelitian ini menunjukkan bahwa tantangan moderasi Islam yang digagas mereka adalah bangkitnya kelompok konservatif yang mendapat ruang luas saat ini. Tulisan ini menekankan bahwa kebangkitan kelompok konservatif telah mengakibatkan lemahnya rasa hormat terhadap kelompok lain. Bahkan ada kecenderungan untuk mengingkari kelompok Islam itu sendiri di luar kelompoknya. Tulisan ini masih terbatas pembahasannya pada tantangan internal yang dilakukan oleh Muhammadiyah dan NU terkait moderasi Islam di Indonesia khususnya kebangkitan kelompok Islam konservatif. Oleh karena itu, tulisan ini menyarankan untuk melakukan berbagai kajian yang lebih luas guna memberikan kerangka dasar untuk bersama-sama membangun komitmen mewujudkan moderasi Islam di Indonesia dengan melihat organisasi masyarakat sipil lainnya.

Kata Kunci: Konservatisme; moderasi Islam; organisasi Islam; pengakuan social; tantangan. 


\section{Introduction}

Muhammadiyah and Nahdlatul Ulama (NU), the two most prominent Islamic organisations in Indonesia (Darajat, 2017), have made moderation a missionary vision from the start with a different $d a^{\prime}$ wah model. Although both $d a^{\prime} w a h$ is based on the Qur'an and Hadith and the noble values of the nation, efforts to realise religious moderation are not free from obstacles that come from internal Islam. Various intolerant actions occurred in the name of Islam targeting minority religious groups, for example, became an alarm for the challenges to these efforts. The Setara Institute in 2019 released the development of cases of intolerance in Indonesia, showing violation cases concerning religious rights. From 2014 to 2019, 655 topics were reported as legal violations against religious rights. These cases involved Islamic groups with various arguments, such as enforcing Islamic $d a^{\prime} w a h$. Not a few experts see that these actions are the impact of the strengthening of conservative Islam (Burhani, 2016; Juliandi, Ibrahim, \& Herlambang, 2018; Mudzakkir, 2017; D. Wahid, 2014), which is placed as one of the triggers for the growth and development of these actions of intolerance in the last decade in Indonesia. For example, Najib Burhani (2016) sees the incident not as a representation of the Indonesian Muslim, but as the result of a coalition of conservative groups that have different, even contradictory, theological orientations.

Many experts have conducted various studies on religious moderation. Existing studies, in general, can be seen in three trends. First, the research emphasises the efforts made by multiple parties to support the religious moderation, including those carried out institutionally by Islamic organisations such as Muhammadiyah and NU (Al-Rasyid, 2014; Faiqah \& Pransiska, 2018; Harto \& Tastin, 2019; Mubarok \& Rustam, 2018; Purwanto, Qowaid, Ma'rifataini, \& Fauzi, 2019). These studies emphasise the importance of involving all elements, especially non-state elements, in efforts to realise moderation. Second, studies see opportunities to discover religious moderation in multicultural Indonesia (Akhmadi, 2019; Amin, 2014; Deny Irawan, 2018; Mubarok \& Rustam, 2018; Syifa, 2019). One of the great opportunities here is the fact of diversity of the nation that enables the studies to explore various forms of moderation. This diversity is a substantial capital for a more open religious life amid various cross-interests, including strengthening ethnic and religious identities. Third, studies place moderation as a medium/means to support or guarantee a more harmonious and open life (Corbett, 2016; Subkhan, 2019; Widodo, 2019; Yahya, 2020). In this case, Islamic moderation can be a common path in realising a more egalitarian, balanced, and inclusive life. The three trends of the study conceptually and paradigmatically have provided a strong foundation for efforts to learn religious moderation. However, these studies have not explicitly provided predictions on various threats that could hinder the pace of this strategic effort.

This paper aims to provide an explanation that conservatism hinders the realisation of religious moderation in Indonesia. Martin van Bruinessen (2013) has discussed Islamic conservatism, which can reduce the spiritual authority of Islamic organisations, but has not comprehensively explained the threat of Islamic conservatism to the realisation of Islamic moderation, especially in Indonesia. In this regard, several questions are answered sequentially in this article. First, how do Muhammadiyah and NU in Indonesia promote religious moderation? In this case, what are the efforts made by both of them in realising religious moderation? Second, how can conservatism (Islam) hinder the pace of the two Islamic organisations' actions? What is the impact of strengthening Islamic moderation by NUMuhammadiyah on the future of Indonesian Islam?

This paper is based on the assumption that, first, the efforts to achieve religious moderation by Muhammadiyah and NU still leave gaps so that what they are doing has not shown maximum results. Consolidation of Islamic organisations is still ongoing, so concentrating on promoting the grand vision of moderation is slow. Second, the rise of conservative groups is an obstacle to moderate efforts by Islamic civil groups. In addition to bringing different religious understandings, conservative groups also carry the theme of Islam, which is contrary to the plurality of the nation's culture. Third, the lack of respect for the existence of other groups is the impact caused by the strengthening of conservative understanding within Islam, which opens opportunities for the weakening of Islam on the one hand and the occurrence of divisions on the other hand. 


\section{Religious Moderation Discourse}

The concept of moderation in religion has a broad spectrum. While aspects of religion are often associated with religious symbols and practices at the current social level, moderation emerges from the phenomena that preceded it. In Brocker view (2013, p. 171), moderation is an adaptation of public elections, peace, and non-confrontation strategies that seek compromise and peaceful dispute resolution at a non-electoral, provocative, and aggressive approach that avoid violence but may require controversial action. Meanwhile, in Islam, religious moderation appears in the teachings of Wasatiyah Islam (Islamic moderation). Wasatiyah Islam has become a direction or school of Islamic thought that has become an essential discourse, considering that Muslims are always accused in every incident of violence committed personally by Muslims who do not understand the character and teachings of Islam (Arif, 2020; I. Ibrahim, Prasojo, \& Sulaiman, 2019).

In addition, Wasathiyah Islam or Islamic Moderation emerged as a counterweight to groups that often accused other groups of being heretical and apostate (takfiri). Wasathiyah education itself is an understanding of moderate Islam, with the idea of opposing violence, fanaticism, and extremism, defending the oppressed, and rejecting intimidation, and terrorism (Fitri, 2015). Moderation is an option to fight radicalism or extremism as Ibrahim (2018) wrote:

The issue of moderation has been chosen to counter the pressing issue today, which is extremism.

This is crucial since, at present, religion and tradition have been accused of hosting the idea of extremism and held responsible for infusing its 'idea' to the extremist followers.

Furthermore, Kamali (2015) asserts that moderation or wasatiyyah (Arabic synonym: tawassut, $i$ tidāl, tawāzun, iqtișād) is very much in line with the concept of justice, which means choosing a position in the middle between the points of extremities. Kamali $(2015$, p. 9) further states that moderation or wasatiyyah is defined as "an attitude that is recommended for people of reason, which can be distinguished from their aversion to extremism or the manifestation of neglect."

Wasathiyah is an Islamic teaching that directs its people to be fair, balanced, beneficial, and proportional, often referred to as "moderate" in all dimensions of life. Wasathiyah manifests itself in Islamic attitudes and is inclusive, humanist, and tolerant (Anshori, Prasojo, \& Muhtifah, 2021; Niam, 2019). The concept of ummatan wasathan and wasathiyah Islam in the Middle East emerged as a response by intellectuals to the increasing trend of extremism that emerged among Muslims in the region (Diyani, 2019). In line with that, the concept of Islamic moderation or wasathiyatul Islam emerged due to concerns about two schools of thought and movements in the name of Islam. The first idea and movement are rigid ones that perceive Islam as a textual and constant religion that does not accept changes and discussions in its teachings, especially in matters of faith, worship, law, and muamalat This thought triggered terrible stigma against Islam as a complex, closed, radical, intolerant, and inhumane religion. Meanwhile, the second thought and movement are the Islamic liberation movement that carries rationalist narratives and beliefs and complete freedom of Islam, which results in Islam having to change and keep up with the times, especially in terms of sharia, worship, law, muamalat, and even faith (Arif, 2020). These thoughts and movements are inclusive and tolerant and position Islam as a responsive and adaptive religion to changes in society.

\section{Islamic Conservatism and Social Recognition}

The phenomenon of religious conservatism has a firm historical and sociological footing (Mudzakkir, 2017). Martin van Bruinessen (2013) defined conservative Islam as a school of thought that rejects reinterpretation of Islamic teachings liberally and progressively and maintains a standardised interpretation and social system (D. Wahid, 2014). Al-Muhafidz is generally defined as conservative; maintaining the prevailing circumstances, habits, and traditions (Kurniawan, 2019). Conservative terminology also refers to an understanding that stops at the realm of literalist understanding and is reluctant to accept differences in interpretation and encourages a person or group to convert that conservative insight into radical behaviour or actions (Maghfuri, 2019). Philosophically, conservative 
thinkers oppose legal change and the application of the law through more liberal interpretations. The ideas promoted by the conservatism group contradict the beliefs that tend to be liberal and progressive.

Conservative groups have a goal to return to the Qur'an and Sunnah, improve Islamic beliefs and morality, and revitalise the Islamic world intellectually, economically, and politically. They also attempted to strengthen Islamic communities and protect them from attacks of internal and external enemies and ensure the relevance of Islam in Muslim life in all dimensions (Manan, 2017). In Indonesia, Bruinessen cited several explanations for why conservatism has reappeared; first, the relationship between democratisation and the fading influence of liberal and progressive Islamic views; second, the strengthening of Middle Eastern power. In this case, alumni of universities in the Middle East, especially Saudi Arabia, spread a literal and scripturalist style of understanding Islam to the public in Indonesia (van Bruinessen, 2013).

Human life is constantly faced with plurality phenomena such as ethnic and religious plurality, which often triggers divisions. With this reality, a strategy is needed to bridge the existing gaps with various accommodation types to bring together the two poles to understand and recognise a culture (Muslim, 2013). Social recognition is significant to overcome multiple forms of injustice that befall the subject in the social order (Runesi, 2015). Social recognition is a broad concept that people give to each other in all social interactions (Rottiers, 2010). Social recognition, such as that based on Taylor's thinking, is generally built on socially derived identities based on the fact that recognition is based on social categories (Taylor, 1994). Everyone has the right to be given and to receive (M. Wahid, 2018).

Taylor (1994) added that social recognition is carried out with two actions: (1) respecting an individual by giving him several public awards, (2) equal treatment to protect one's dignity and right to be respected (M. Wahid, 2018). Social recognition is also shown in the respect and equal treatment of marginalised and demeaned identities. Social recognition is significant in multicultural societies to avoid discrimination. Discrimination that often occurs in multicultural societies, such as what happened in Indonesia, is the loss of rights of non-mainstream religious groups, especially indigenous religious groups in the Indonesian archipelago (Sudarto, 2019), as in the case of the group of Sunda wiwitan teachings in Cigugur, Kuningan which experienced discrimination by the adherents of other religion such as the prohibition of conducting religious activities of the Sunda Wiwitan teachings, systematic conditioning so that its followers converted to a religion recognised by the state, and even acts of physical harassment (Jubba, Pabbajah, H Prasodjo, \& Qodir, 2019; Sabandiah \& Wijaya, 2018). Likewise, attacks on Ahmadiyah congregations in West Java occurred where their rights as religious adherents are disrupted by claims of "being heretical" or "being apostate" against the congregations (Sajari, 2015).

This article will explore the mission and style of $d a^{\prime} w a h$ of Muhammadiyah and NU to realise a moderate religious life, not only for Muslims but also for all human beings. It also analyses the concept of Islamic conservatism to see whether this pattern of thinking impacts the order of religious life in Indonesia, including social relations between religious groups. The multicultural character of the Indonesian nation requires a medium that simultaneously bridges the growth and development of Islamic practices on the one hand and provides opportunities for the existence of other religious groups to practice their spiritual teachings on the other. Meanwhile, social recognition is intended to explain that Islamic conservatism impacts more generous social spaces.

\section{The Mission to Realise Religious Moderation}

Muhammadiyah and Nahdlatul Ulama are the two main pillars of Indonesian civil society, which have continued to be wise to the nation for the benefit of humanity as a whole (Nashir, 2019). Muhammadiyah, through "Advanced Islam" and Nahdlatul Ulama with "Islam Nusantara," both have big visions to present a more humanist Islam by placing it as a religion that protects all God's creation. Islam is a religion of tolerance, peace, and inclusion (Hasan, 2017). Islam is not only mercy for its worshipers but all creatures on earth. These two organisations even place "humanity" as the fundamental spirit in everyone. Muhammadiyah and Nahdlatul Ulama promote engagement with other religions (Asroor, 2019). Islam that is promoted by these two organisations is Islam that 
accommodates the local context. What happened in Arabia in the early Islamic era was maintained by juxtaposing it with Indonesian society to create a distinctive form of Islamic practice. The commitment and efforts to spread the Islamic spirit of these two organisations gain a place in the community even though they are segmented into several small groups with different religious understandings and practices. The fact that moderation as a concept is found in other religions and traditions justifies the idea that moderation is, in fact, a universal idea (Nashir, 2019).

The 47th Muhammadiyah Congress in Makassar and the 33rd NU congress in Jombang in 2015 produced several important formulations to realise a more inclusive religious life in Indonesia. Muhammadiyah Congress held from the third until August 07, 2015 carried the theme "Renewal Movement towards a Progressive Indonesia", focusing on the praxis of the enlightenment movement to liberate, empower, and advance life. Liberation in this context means releases humans from ignorance, poverty, backwardness, and various other unfavourable conditions. As for enlightenment, it concerns how spiritually enlightened moral crises are resolved and violence and conflict are avoided. The Muhammadiyah enlightenment movement rests on how social relations are built in a just manner without discrimination, promoting human dignity, tolerance, and pluralism and creating major social institutions (Nashir, 2019).

Meanwhile, through the theme of "Strengthening Nusantara Islam for Indonesian and World Civilisation," NU is also committed to building a tolerant and peaceful civilisation (Mustofa, 2015). NU not only focuses on the textual affirmation of Islamic ideology but also on how Islamic values are manifested into real contexts. These two pillars of Islam position da'wah as a medium for disseminating teachings that cover all aspects through an encouraging and friendly method. In this case, both Muhammadiyah and NU move in the same direction, which is a human benefit without discrimination. Muhammadiyah's da'wah movement, known as the Amar ma'ruf nahi munkar, is focused on education and health, which are open to all people regardless of their religion. PKO (Penolong Kesengsaraan Oemoen) was established to help Muslims and all people and to help the poor.

PKU (formerly PKO: Penolong Kesengsaraan Oemoen/Umum) was established in Surabaya in 1924 and was not at all aimed at Islamising non-Muslims. PKU is purely to help people, especially people who have difficulty getting treatment. PKU was standing with a lot of help from Dutch and Christian nurses at that time" (AM, Muhammadiyah Leader, Personal Communication, September 10, 2020).

Dr. Soetomo stated in the opening speech of the PKO as follows.

Tomorrow morning, we will open this clinic. Anyone, whether European, Javanese (native), Chinese or Arab, may come here, they will be helped [with] free of charge, as long as they are inferior" (Mulkhan, 2010, p. 84).

This affirmation proved that the health services were not limited to Muslims or Muhammadiyah members but were open to anyone who needed assistance and it did not have an ideological mission. Likewise, Muhammadiyah educational institutions such as schools and universities are not intended for only Muhammadiyah followers. For example, in various areas such as Papua, West Papua, and West Nusa Tenggara, Muhammadiyah College (PTM) has graduated many alumni from non-Muslim circles. One of the young Muhammadiyah leaders, FS, said, "There are more non-Muslim students here. Those who are non-Muslims are mostly Papuans. Students are also not required to wear the hijab. They enjoy the learning process" (FS, Personal Communication, October 02, 2020).

In Java itself, where Muslims dominate, not all PTM students have a Muhammadiyah background. This situation shows that Muhammadiyah's $d a^{\prime} w a h$, which is manifested in lectures and recitations and business charity, does not form its exclusive line because the primary mission of Muhammadiyah's $d a^{\prime}$ wah is how to give benefit and for humanity.

The Muhammadiyah $d a^{\prime}$ wah movement is called amar ma'ruf nahi munkar as the method of choice. Amar ma'ruf (inviting to the good deed) and nahi munkar (staying away from evil) are based on the call to always do good and stay away from wrong actions without discriminating against other people. $D a^{\prime} w a h$ 's target with this fundamental principle is for Muslims and all creatures to achieve a more 
harmonious-humanist life. Muhammadiyah's $d a^{\prime}$ wah is more prominent with "Progressive Islam" as a style without reducing the basic principles. The arguments extracted from the Qur'an and Sunnah are understood both textually and contextually to be more flexible and readily accepted by the Muslim community. Muhammadiyah's da'wah is reflected in business charities, especially in education and health.

In education, the enemy of Islam is not certain groups such as groups outside Islam, but ignorance. In the health sector, the primary mission of establishing hospitals and clinics is to ensure health facilities are accessible to all groups and can heal illness quickly without questioning the patient's (religious) background. Therefore, educating and treating are not intended for specific groups but everyone in need without discrimination.

Meanwhile, Nahdlatul Ulama (NU), through its cultural propaganda package, carries a similar theme to that of Muhammadiyah, which is realising a friendly, open, and tolerant Islam. NU's $d a^{\prime} w a h$ style combines Islam and local culture. This type of $d a^{\prime} w a h$ is not new to Islam in Indonesia. NU's cultural $d a^{\prime}$ wah was inspired by Walisongo and later scholars in the Indonesian archipelago. Muslims who are still heavily influenced by the Hindu-Buddhist tradition face an approach that should not erase old habits and should combine Islamic values in the $d a^{\prime}$ wah process instead. Previous scholars' thoughts and models influenced NU's da'wah. Those scholars are Shaykh Abd Rauf al-Singkili al-Jawi, Shaykh Yusuf al-Makassari, Shaykh Abd al-Muhyi Pamijahan, Hamzah Fansuri, Muhammad Nawawi alBantani, Muhammad Nafis al-Banjari, and others. Hasyim Asy'ari and several other prominent scholars then continued the mission.

NU's cultural $d a^{\prime} w a h$ is driven by the reality that Islam and community traditions live together. This $d a^{\prime}$ wah pattern was also an option as accommodation for Islam towards the culture by making changes. Hence, the people could accept Islam at that time. This cultural $d a^{\prime} w a h$ rests on the mainstreaming of Islam which has those characteristics since cultural da'wah requires high tolerance, moderation, cooperation, equal rights, and justice. The basic principles of NU's cultural $d a^{\prime} w a h$ are based on tawassuth (moderation), tawazun wa i'tidal (balance), tasamuh (tolerance), and Amar ma'ruf nahi munkar (Asmar, 2018). These four principles are the basis for their da'wah to this day. Of these four principles, Fealy (1997, p. 225), citing KH. Ahmad Shiddiq, stated that radicalism and criticism of the government are not a tradition at NU because it does not follow tawassuth (moderation). Although this statement explains NU in the 1970s, moderation, and disagreement with radicalism have been running for a long time.

NU's moderation attitude is Jam'iyah Diniyah Islamiyah. In figh, NU follows the four schools (madhhab) of Syafii', Hanafi, Maliki, and Hambali. Meanwhile, in aqeedah, NU follows Abu Hasan alAsyari and Abu Mansur al-Maturidi (Almu'tasim, 2019). The cultural $d a^{\prime}$ wah movement in society has strong roots in classical turats. Therefore, turats wal hadatsah (tradition and modernity) became the key in cultural $d a^{\prime}$ wah movements by NU. It later became known as the adage al-muhafadzah ala al-qadim alshalih wa al-akhdu bi al-jadid al-ashlah (maintaining good old traditions while adopting new and better practices) (Sunarto, 2013). This adage emphasises that NU is placed in the middle position in developing its $d a^{\prime}$ wah.

Both Muhammadiyah and NU have introduced and practiced Islamic wasatiyah in da'wah and social movements to various societal levels without distinction of status and social identity, including religion. The mission is the same: to prove Islam as a religion of grace. Islam is a source of inspiration for life, including social and even political life. What is shown by both of them not only confirms the commitment to manifest Islam in real terms in various aspects of life but also explains the preservation of the religious spirit, which is institutionally the foundation of Indonesian Muslims. The idealised Islam is Islam where the public interest is the meeting point of all efforts made. In this case, the da'wah is a moderate-substantive paradigm that directly contrasts the formalistic-integralist paradigm in recent years. 


\section{The Rise of Islamic Conservatism: A Challenge of Moderation}

Muhammadiyah and NU are currently dealing with the revival of conservative Islamic movements. On the one hand, these new movements are seen as bringing new enthusiasm for Islamic da'wah in the region, but on the other hand, they are also seen as a threat to familiar religious practices (Lanti, Akim, \& Dermawan, 2020). Looking back at the various actions of Islamic groups in the New Order era, every activity was closely monitored so that almost no movement led to criticism of the regime. This condition changed after the New Order when Islamic movements promoted and affirmed moderate Islam and a formal pro-Islamic attitude and criticised the regime. Movements in Islam rose and carried big themes such as Islamic formalism, including in-state life. This Islamic revival is also a conservative turn (van Bruinessen, 2013). Conservative turn triggers political turmoil, especially in Islam. Various forms of intolerance have emerged in Indonesia.

A memorable case of intolerance and political turmoil in the case of the governor and deputy governor of DKI Jakarta in 2017. Thousands of people joined in a demonstration against Ahok (Basuki Cahaya Purnama). In this case, several Islamic figures saw that conservative Islam coincides with the "erosion" of the function of Muhammadiyah and NU as strongholds of Islamic moderation. The fighting spirit of these two Islamic civil organisations has weakened and cannot control their respective masses (D. Wahid, 2014). 212 and 411 Movements, for example, were attended by Muhammadiyah-NU masses and a combination of various other Islamic organisations. The internal part of Islam was experiencing "depreciation" and weakening of solidity resulting in "wild" movements. One of the important figures of Muhammadiyah explicitly stated that Muslims, not only those of Muhammadiyah and NU but also other Muslim groups in the world, experienced a degradation of the spirit to realise Islamic moderation. He stated, "The weak fighting spirit is a disease of all moderate Muslim movements in the world" (USA, Personal Communication, August 25, 2020).

The rise of conservative Islamic groups is recognised as a threat to life, as evidenced by history showing that conservatism breeds acts of intolerance (Mudzakkir, 2017). In this case, conservative Islam is factually a challenge for the realisation of Islamic moderation today. AM, a Muhammadiyah figure, stated:

The serious challenge of religious moderation, especially Islamic [moderation], is from within Islam itself. In Muhammadiyah, it is the development of Muhammadiyah Ikhlas and Muhammadiyah Salafi. In NU, the paramilitary groups that are ultra-NU and ultra-nationalist have developed. It has a strong influence on these two masses (AM, Muhammadiyah Leader, Personal Communication, August 25, 2020).

This assertion was also acknowledged by HS, a prominent NU figure, stating that:

Conservatism and radicalism movements are a real challenge for religious moderation in Indonesia because this idea leads to a setback to damage the tradition of diversity, especially NU, and create social conflicts between religious communities and even within Islam (HU, Personal Communication, August 25, 2020).

Various ummah problems experienced by Indonesian Muslims have triggered multiple responses, including the counter-productive efforts to the spirit of religious moderation. The moral decline that occurs in all age groups, for example, begins acts of violence in the name of Islam. Likewise, the economic difficulties experienced by the community resulted in a form of "recklessness" in acting even though what they did was a deviant act both according to legal and religious norms. The gap in thinking between the Islamic elite and the ummah is also a problem for the smooth growth of conservative ideas. The elite has not interpreted Islam well and quickly chooses a more straightforward style of Islam. One of NU's academics and youth leaders, SQ, said:

Now there is conservatism among Muslims because most of them still hold on to old traditions that tend to be conservative and do not lead to change. The contributing factor is the knowledge gap between the elites and the people. The life experiences gained by some people have created antipathy towards the moderation movement and religious pluralism. Moreover, the benefits of 
defending moderation are not yet clear for the survival of the people (SQ, Personal Communication, July 28, 2020).

The moderate position of Muhammadiyah-NU is considered by conservative groups as a way to weaken faith and Islam itself. There is a counter-discourse on religious moderation because it is an effort to weaken the internal organisation of Islam. PH, a young NU leader and administrator of Lakpesdam, said:

The challenges, according to my observations, come from new Islamic puritanism groups such as the Salaf group and political Islam movements such as the HTI. Meanwhile, we (NU), who always carry the jargon of moderate Islam, are even considered to weaken the faith of Muslims ( $\mathrm{PH}$, Personal Communication, July 28, 2020).

Besides internal challenges, the outside world also threatens Islamic moderation in Indonesia, as recognised by MS, a NU academic. He said:

There are two serious challenges to Islamic moderation today, [from] inside and outside. From the inside, there are differences in political choices that have not been addressed maturely. Different Islamic groups are considered opponents. Likewise, there is a gap of knowledge among religious elites and laymen about pluralism and tolerance. The fact that we are ignored [is] because we only care about our group. The most visible external challenge is the transnational Islamic movement that enters and is not filtered by Islamic groups. "[When] External culture is imposed in Indonesia, which has its [own] culture, it never meets its ideas, including [its idea of] Islam (MS, Personal Communication, July 29, 2020).

This transnational movement has even entered the heart of Muslims through institutions and donations. "There are transnational ideologies that enter either through mosques, business charities, or other media. In West Kalimantan, AMCF (Asia Muslim Charity Foundation-ed) established Ma'had Al Khansa and has its office in the PWM building. Many of the preachers produced tend to be salaf", said HS, one of the young leaders of Muhammadiyah (HS, Personal Communication, July 29, 2020). A solid internal organisation of Islam with excessive traditionalism, liberalism, and revivalism creates solid fanaticism. It does not open up space for dialogue interaction, especially with other Islamic groups (Rohmatika \& Hakiki, 2018). On the other hand, Islamic moderation can contribute to and encourage the progress of science, culture, and economy.

Information from several figures above shows that Islamic understanding, which tends to be conservative, provides room for the growth and development of rigid, or even harsh, Islamic practices. The strengthening of Islamic conservatism cannot be separated from influences from outside Indonesia that have the intersection of ideologies. The religious spirit always returns to the teachings of the Qur'an and Sunnah. Several conservative Muslims have no sufficient knowledge in understanding Islam. Yet, many of them claimed that their understanding is right while others are wrong, and even accused as an infidel. The positions do not provide a place for other religious groups even though the groups are also Muslims because rigid, textual, and literal Islamic understanding is growing in the Islamic world, including in Indonesia. Differences in interpretation are even understood as contradictory conditions to address contrasting and partial actions.

\section{Crisis of Social Recognition}

Other groups' lack of recognition weakens Islamic conservatism in Indonesia. Conservatism coincides with the strengthening of practices that adopt the terminology "the other and us", Minna wa minkum. In this case, there is a clear distinction between members of one group and other groups. Not only differentiation but also social mapping tends to deny each other, even kill each other. The Setara Institut report also explained rampant acts of violence in the community that make differences a trigger. The Wahid Institute also released its annual report on Freedom of Religion (KBB) in 2019, where there were 184 cases of violations (intolerance) with 215 incidences. Of the 184 cases, 30 cases were hated speech against other groups and accusing another Muslim(s) of apostasy (takfiri) and were followed by violence from both state and non-state actors. Non-state actors are civil societies and institutions that 
are violent and do intolerant activities. Victims of this prejudiced case included 30 religious groups or sects and 19 issues against Christian groups.

Religious minority groups are the targets of intolerant actions of certain religious groups The Ahmadiyya community has fallen victim to intolerance due to a monopoly on a proper interpretation of sacred texts by certain groups. The truth claims that only come from the majority directly closes the opportunity for understanding from the minority side. This situation has an impact on the singularity of the truth. The truth claim exists in the traditions of religions. However, this claim provides a vast space for the majority group (of Abrahamic religions) to neglect other groups (Tajrid, 2012). In the dynamics of Islam in Indonesia, the interpretation of truth is visible in the dominance of (Sunni) Islam to marginalise other Islamic groups such as Ahmadiyya and Shia communities.

The truth claims that have been going on so far have denied the fact that Indonesian people are plural and do not adhere to the same religion. This claim also denies the universal mandate of faith, which focuses more on prioritizing human dignity and not merely upholding textual teachings (Jubba \& Hidayati, 2018). A truth claim is a statement that only one group is accepted and the right one, while others are wrong. It is a big challenge faced by religious people in creating a peaceful life (Tajrid, 2012). A harmonious life can fail if it intensifies negative sentiments towards religious groups outside a certain group.

\section{Conclusion}

Islamic moderation promoted by Muhammadiyah and NU in Indonesia has not maximally dampened the conservative Islamic movement. The rise of conservatism changed da'wah's direction and the image of Islam, which is a complete and flexible footing of life, into harsh and intolerant ones. Religious moderation is experiencing obstacles in its realisation, along with the more substantial penetration of conservative groups through various da'wah media, including social media, to disseminate influence to society, which gives the impression that Islam is more exclusive and keeps Islam away from its spirit as a religion of grace. What is being promoted by Muhammadiyah and NU in Indonesia today can reflect their commitment to proving that Islam is a religion that becomes a bridge to realise a more humane social life.

Efforts that have been initiated by the mainstream Islamic civic groups in Indonesia face problems when it comes to dealing with conservative Islamic groups. In this case, although religious (Islam) moderation is interpreted as a dignified social life goal, it encounters obstacles when it deals with fellow Muslims from different Islamic groups. The strengthening of conservative Islamic groups is when the flow of unilateral truth claims is getting stronger. Muhammadiyah and NU even tend to be silent and only focus on strengthening their respective organisations. The urge to fight against various movements that lead Islam to closed-mindedness is getting stronger. The majority position of the two organisations that carry moderatism is not visible.

This article only observes the efforts made by two leading mass organisations in Indonesia to realise religious moderation and the challenges from the internal organisation of Islam itself. Therefore, further studies that investigate the challenges of religious moderation that come from outside Islam (external factors) and efforts to realise Islamic moderation carried out by other civil (Islamic) organisations are needed to obtain a more comprehensive study. Likewise, the data used are still onesided, obtained from internal sources of Muhammadiyah and NU. Further studies by taking a broader spectrum will complement this study.

\section{Acknowledgment}

This article is the Overseas Collaborative Research Grant from the Research, Publication, and Community Service Institute (LP3M) Universitas Muhammadiyah Yogyakarta in 2020/2021. 


\section{References}

Akhmadi, A. (2019). Moderasi Beragama Dalam Keragaman Indonesia Religious Moderation in Indonesia ' S Diversity. Jurnal Diklat Keagamaan, 13(2), 45-55.

Al-Rasyid, H. H. (2014). Dakwah Islam di Era Globalisasi: Revitalisasi Prinsip Moderasi Islam. Al-Qalam, 20(3), 112. https://doi.org/10.31969/alq.v20i3.337

Almu'tasim, A. (2019). Berkaca NU dan Muhammadiyah dalam Mewujudkan Nilai-Nilai Moderasi Islam di Indonesia. Tarbiya Islamia: Jurnal Pendidikan Dan Keislaman, 8(2), 199-212. https://doi.org/10.36815/tarbiya.v8i2.474

Amin, R. (2014). Prinsip Dan Fenomena Moderasi Islam Dalam Tradisihukum Islam. Al-Qalam, 20(3), $23-32$. https://doi.org/10.31969/alq.v20i3.339

Anshori, M. A., Prasojo, Z. H., \& Muhtifah, L. (2021). Contribution of Sufism to the Development of Moderate Islam in Nusantara. International Journal of Islamic Thought, 19(1), 40-48. https://doi.org/10.24035/ijit.19.2021.194

Arif, M. K. (2020). Moderasi Islam (Wasathiyah Islam) Perspektif Al-Qur'an, As-Sunnah Serta Pandangan Para Ulama dan Fuqaha. Al-Risalah, 11(1), 22-43. https://doi.org/10.34005/alrisalah.v11i1.592

Asmar, A. (2018). Genealogi dan Strategi Dakwah Kultural NU. Islamica: Jurnal Studi Keislaman, 13(1), 165-184. https://doi.org/10.15642/islamica.2018.13.1.164-183

Asroor, Z. (2019). Islam Transnasional vs Islam Moderat: Upaya NU dan MD dalam Menyuarakan Islam Moderat di Panggung Dunia. AT-TURAS: Jurnal Studi Keislaman, 6(2), 31-73. https://doi.org/10.33650/atturas.v6i2.807

Brocker, M., \& Künkler, M. (2013). Religious parties: Revisiting the inclusion-moderation hypothesis1 Introduction. Party Politics, 19(2), 171-186. https://doi.org/10.1177/1354068812473673

Burhani, A. N. (2016). Aksi Bela Islam: Konservatisme dan Fragmentasi Otoritas Keagamaan. Jurnal Maarif Institute, 11(2), 15-29.

Corbett, R. R. (2016). Making Moderate Islam: Sufism, Service, and the "Ground Zero Mosque" Controversy. Stanford: Stanford University Press.

Darajat, Z. (2017). Muhammadiyah dan NU: Penjaga Moderatisme Islam di Indonesia. Hayula: Indonesian Journal of Multidisciplinary Islamic Studies, 1(1), 81-96. https://doi.org/10.21009/hayula.001.1.05

Deny Irawan, M. (2018). Islam Waşatiyyah: Refleksi antara Islam Modern dan Upaya Moderasi Islam. TAJDID: Jurnal Ilmu Ushuluddin, 16(2), 111-128. https://doi.org/10.30631/tjd.v16i2.57

Diyani, T. (2019). Implementasi Paradigma Islam Wasathiyah; Strategi Menjaga Masa Depan Keindonesiaan. SALAM: Jurnal Sosial Dan Budaya Syar-I, 6(3), 303-316. https://doi.org/10.15408/sjsbs.v6i3.13193

Faiqah, N., \& Pransiska, T. (2018). Radikalisme Islam Vs Moderasi Islam: Upaya Membangun Wajah Islam Indonesia Yang Damai. Al-Fikra: Jurnal Ilmiah Keislaman, 17(1), 33-60.

Fealy, G. (1997). Tradisionalisme Radikal: Persinggungan Nahdlatul Ulama-Negara. Yogyakarta: LKiS.

Fitri, A. Z. (2015). Pendidikan Islam Wasathiyah: Melawan Arus Pemikiran Takfiri Di Nusantara. Kuriositas: Media Komunikasi Sosial Dan Keagamaan, 8(1), 45-54.

Harto, K., \& Tastin, T. (2019). Pengembangan Pembelajaran Pai Berwawasan Islam Wasatiyah: Upaya Membangun Sikap Moderasi Beragama Peserta Didik. At-Ta'lim : Media Informasi Pendidikan Islam, 18(1), 89-110. https://doi.org/10.29300/attalim.v18i1.1280

Hasan, M. (2017). Moderasi Islam Nusantara: Studi Konsep dan Metodologi. Pamekasan: Duta Media Publishing.

Ibrahim, H. (2018). The Principle of Wasațiyyah (Moderation) and the Social Concept of Islam: Countering Extremism in Religion. Al-Itqan: Journal Of Islamic Sciences and Comparative Studies, 2(1), 39-48.

Ibrahim, I., Prasojo, Z. H., \& Sulaiman, S. (2019). Preventing Radicalism: Islamic Moderation and Revitalization in the Border. Wawasan: Jurnal Ilmiah Agama Dan Sosial Budaya, 4(1), 1-15. https://doi.org/10.15575/jw.v4i1.4400

Jubba, H., \& Hidayati, M. (2018). Religious Violence in the Indonesian Democratic Era. Al-Albab, 7(1), 3-16. https://doi.org/10.24260/alalbab.v7i1.935

Jubba, H., Pabbajah, M., H Prasodjo, Z., \& Qodir, Z. (2019). The Future Relations between the Majority and Minority Religious Groups, Viewed from Indonesian Contemporary Perspective: A Case Study of the Coexistence of Muslims and the Towani Tolotang in Amparita, South Sulawesi. International Journal of Islamic Thought, 16(1), 13-23. https://doi.org/10.24035/ijit.16.2019.002

Juliandi, B., Ibrahim, B., \& Herlambang, S. (2018). Politik dan Konservatisme Islam: Indonesia dan Tunisia. Proceedings of Annual Conference for Muslim Scholars, 913-921.

Kamali, M. H. (2015). The Middle Path of Moderation in Islam: The Qur'añic Principle of Wasatiyyah. Oxford: Oxford University Press.

Kurniawan, F. (2019). Pengembangan Teori Pendidikan Islam Perspektif Muhammad Jawwad Ridla (Religius 
Konservatif, Religius Rasional, Pragmatis Instrumental). At-Ta'lim : Media Informasi Pendidikan Islam, 18(1), 223-242. https://doi.org/10.29300/attalim.v18i1.1823

Lanti, I. G., Akim, \& Dermawan, W. (2020). Examining the growth of Islamic conservatism in Indonesia. In Rising Islamic Conservatism inIndonesia (pp. 54-79). Abingdon, Oxon ; New York, NY : Routledge, 2021. | Identifiers: LCCN 2020021900 (print) | LCCN 2020021901 (ebook) | ISBN 9780367819415 (hardback) | ISBN 9781003010920 (ebook): Routledge. https://doi.org/10.4324/9781003010920-4

Maghfuri, A. (2019). Peran Lembaga Pendidikan Dalam Pengarusutamaan Islam Moderat Sebagai Upaya Melawan Paham Konservatif-Radikal. TADRIS: Jurnal Pendidikan Islam, 14(2), 247-260. https://doi.org/10.19105/tjpi.v14i2.2713

Manan, M. A. (2017). Pemikiran Pembaruan Dalam Islam: Pertarungan Antara Mazhab Konservatif Dan Aliran Reformis. Masyarakat Indonesia, 37(2), 237-258.

Mubarok, A. A., \& Rustam, D. G. (2018). Islam Nusantara: Moderasi Islam di Indonesia. Jurnal of Islamic and Humanities, 3(2), 153-168.

Mudzakkir, A. (2017). Konservatisme Islam dan Intoleransi Keagamaan di Tasikmalaya. Harmoni, 16(1), 57-74. https://doi.org/10.32488/harmoni.v16i1.56

Mulkhan, A. M. (2010). Kiai Ahmad Dahlan: Jejak Pembaruan Sosial dan Kemanusiaan. Jakarta: Kompas Media Nusantara.

Mustofa, S. (2015). Meneguhkan Islam Nusantara untuk Islam Berkemajuan: Melacak Akar Epistemologis dan Historis Islam (di) Nusantara. Epistemé: Jurnal Pengembangan Ilmu Keislaman, 10(2), 405-434. https://doi.org/10.21274/epis.2015.10.2.405-434

Nashir, H. (2019). Pidato Pengukuhan Guru Besar: Moderasi Indonesia Dan Keindonesiaan Perspektif Sosiologi. Yogyakarta.

Niam, Z. W. (2019). Konsep Islam Wasathiyah Sebagai Wujud Islam Rahmatan lil ‘alamin: Peran Nu dan Muhammadiyah dalam Mewujudkan Islam Damai di Indonesia. Palita: Journal of Social Religion Research, 4(2), 91-106. https://doi.org/10.24256/pal.v4i2.764

Purwanto, Y., Qowaid, Q., Ma'rifataini, L., \& Fauzi, R. (2019). Internalisasi Nilai Moderasi Melalui Pendidikan Agama Islam di Perguruan Tinggi Umum. EDUKASI: Jurnal Penelitian Pendidikan Agama Dan Keagamaan, 17(2), 110-124. https://doi.org/10.32729/edukasi.v17i2.605

Rohmatika, R. V., \& Hakiki, K. M. (2018). Fanatisme Beragama Yes, Ekstrimisme Beragama No; Upaya Meneguhkan Harmoni Beragama Dalam Perspektif Kristen. Al-Adyan: Jurnal Studi Lintas Agama, 13(1), 122. https://doi.org/10.24042/ajsla.v13i1.2940

Rottiers, S. (2010). The sociology of social recognition: competition in social recognition games. Encyclopedia of Animal Behavior, 10(4), 267-272.

Runesi, S. T. (2015). Pengakuan sebagai Gramatika Intersubjektif Menurut Axel Honneth. MELINTAS, $30(3), 323$. https://doi.org/10.26593/mel.v30i3.1449.323-345

Sabandiah, R. N., \& Wijaya, E. (2018). Diskriminasi terhadap Agama Tradisional Masyarakat Hukum Adat Cigugur. Jurnal Penelitian Hukum De Jure, 18(3), 335. https://doi.org/10.30641/dejure.2018.V18.335-352

Sajari, D. (2015). Fatwa MUI Tentang Aliran Sesat di Indonesia (1976-2010). MIQOT: Jurnal Ilmu-Ilmu Keislaman, 39(1), 44-62. https://doi.org/10.30821/miqot.v39i1.38

Subkhan, A. (2019). Semangat Moderasi dalam “Watsiiqoh Al-Ikhwah Al-Insaniyah Min Ajli As-Salaam Al'Alamy Wa Al-'Aisy Al-Mustarok". Jurnal Edutrained: Jurnal Pendidikan Dan Pelatihan, 3(2), 135-151. https://doi.org/10.37730/edutrained.v3i2.7

Sudarto, S. (2019). Rekognisi Agama Lokal Prasyarat Menuju Demokrasi Majemuk. FUADUNA : Jurnal Kajian Keagamaan Dan Kemasyarakatan, 3(2), 92-105. https://doi.org/10.30983/fuaduna.v3i2.2547

Sunarto, A. (2013). Paradigma Nahdlatul Ulama Terhadap Modernisasi. The Sociology of Islam, 3(2), 51-74.

Syifa, M. M. (2019). Formulasi Konsep Moderasi Islam M Mucharom Syifa. Jurnal Ilmiah Mahasiswa Raushan Fikr, 8(1), 31-41. https://doi.org/10.24090/jimrf.v8i1.2716

Tajrid, A. (2012). Kebenaran Hegemonik Agama. Walisongo: Jurnal Penelitian Sosial Keagamaan, 20(1), $193-210$. https://doi.org/10.21580/ws.20.1.190

Taylor, C. (1994). The Politics of Recognition. In A. Gutmann (Ed.), Multiculturalism: Examining the Politics of Recognition. Princeton: Princeton University Press.

van Bruinessen, M. (Ed.). (2013). Contemporary Development in Indonesian Islam, Explaining the "Conservative Turn". Singapore: Institute of Southeast Asian Studies.

Wahid, D. (2014). Kembalinya Konservatisme Islam Indonesia. Studia Islamika, 21(2), 375-390. https://doi.org/10.15408/sdi.v21i2.1043

Wahid, M. (2018). Resolusi Konflik dan Islam Nusantara: Memromosikan Dialog antar Budaya dan Rekognisi Sosial. Refleksi, 15(2), 139-164. https://doi.org/10.15408/ref.v15i2.10164 
Widodo, A. (2019). Moderation of Islamic Education as an Effort to Prevent Radicalism (Case Study of $\{$ FKUB $\}$ Singkawang City, Kalimantan, Indonesia). Nadwa, 13(2), 271-294.

https://doi.org/10.21580/nw.2019.13.2.5086

Yahya, S. (2020). Slogan “Torang Samua Ciptaan Tuhan” dalam Konteks Moderasi Beragama di Kota Manado. Dialog, 43(1), 1-22. https://doi.org/10.47655/dialog.v43i1.361

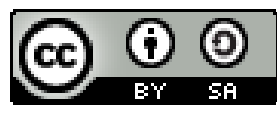

(C) 2021 by the authors. Submitted for possible open access publication under the terms and conditions of the Creative Commons Attribution (CC BY SA) license (https://creativecommons.org/licenses/by-sa/3.0/). 